\title{
Forest Resource Utilization by the Siberut Community and its Implications for the Siberut Island Biosphere Reserve Policy
}

\author{
Fifin Nopiansyah $^{1 *}$, Sambas Basuni ${ }^{2}$, Yohanes Purwanto ${ }^{3}$, Nandi Kosmaryandi ${ }^{2}$ \\ ${ }^{1}$ Graduate School of Bogor Agricultural University, Dramaga Campus, Bogor, Indonesia 16680 \\ ${ }^{2}$ Department of Forest Resources Conservation and Ecotourism, Faculty of Forestry, Bogor Agricultural University, Dramaga \\ Campus, Bogor, Indonesia 16680 \\ ${ }^{3}$ Indonesian Institute of Sciences (LIPI), Cibinong Science Centre, Bogor, Indonesia 16911
}

\section{Received January 11, 2016/Accepted June 3, 2016}

\begin{abstract}
Siberut is one of the islands in the Mentawai group, located off the West Coast of Sumatera in Indonesia. The community of Siberut is well known for their traditional wisdom in utilizing the forest resources and unique biodiversity of their island home. For this reason, Siberut has been officially declared as biosphere reserve. One of the aims the biosphere reserve concept is to enable traditional communities to use their forest resources in a sustainable manner. Unwise activities in the utilization of forest resources have implications for the whole community and for the management of biosphere reserves. This study aimed to compile and analyse first-hand information about current usage offorest resources on Siberut and to identify particular community behavior having implications for the implementation of the Siberut Island biosphere reserve policy. The study was conducted in 3 villages of Siberut traditional communities in Mentawai Islands Regency, that are Matotonan, Saibi Samukop, and Sagulubbek villages. The study applied a qualitative approach, where data were collected through a study of relevant literatures, interviews, and direct observation. Then the data were analyzed to develop an understanding of the current forest utilization and its implications for the policy in accurately. The results showed that the Siberut traditional communities are still dependent on forest resources, even though their utilization practices have been changing in recent times. For example in this research they adopted some new technologies, which it can be destructive to forest resources in the future. For that reason, the reseach suggest the management of Siberut Island Biosphere Reserve to restore those particular aspects of the traditional wisdom which have beneficial for the sustainability of forest resources utilization. In this case involving of local community starting from centre of planning to implementation process will be benefit for a better management of the reserve.
\end{abstract} Keywords: forest resources utilization, Siberut Island Biosphere Reserve, traditional community, sustainable forest,
traditional wisdom

*Correspondence author, email: opinsyah@gmail.com, ph.:+62-812-6752-952

\section{Introduction}

This paper is a report of an investigation into the utilisation of forest resources by the people of Siberut, the northernmost of the Mentawai chain of islands off the West Coast of Sumatera, Indonesia. Siberut is only $4,000 \mathrm{~km}^{2}$ but because of its relative isolation, $150 \mathrm{~km}$ away from the sumatran coast line, it is a location of rich biodiversity. In recognition of this, in 1981 it was declared as biosphere reserve. The study reported here was undertaken to determine how the traditional knowledge of the people of Siberut can be drawn upon to further the aims of the biosphere reserve for long-term sustainable use of the island's forest resources.

Forest resources (FR) are essential resource for the life of traditional communities (Soedjito 2006; Turner et al. 2011).
FR have benefits as sources of food, building materials, clothing, medicines and cosmetics, and for certain social activities (Walujo \& Supardijono 1997). From the forests flow various goods and ecosystem services on which the livelihoods, of traditional communities depend, thus creating a strong bond between the people and their forest (DFID 1999; Dassir 2008; Turner et al. 2011). The dependence of the Siberut community on the biological resources from their forest is a prime example of this (Darmanto 2006; BTNS 2010; Quinten et al. 2014).

Ensuring that local forests remain in good condition to provide FR for traditional communities is an important principle underlying the creation of protected forest areas (Sheil et al. 2006). Nevertheless, traditional communities are not static entities. They interact with the wider society around 
them and rapidly adapt those things that serve their perceived purposes. However, close interaction between such communities and modernizing outside trend scan sometimes produce adverse effects; shifting traditional social values, and weakening communities' relationships with the FR; and undermining established conservation ethics (Suhartini 2009).

The management of an area that provides protection for FR and the community surrounding the area is known as a biosphere reserve. According to Ishwaran et al. (2008), a biosphere reserve is considered as different form of protected area within IUCN criteria; it emphasizes a balance between conservation and development objectives. UNESCO (1996) defined a biosphere reserve as areas of terrestrial and coastal/marine ecosystems, or a combination thereof, which are internationally recognized within the framework of UNESCO's Program on Man and the Biosphere (MAB). Physically, each biosphere reserve should contain 3 elements: one or more core areas, which are securely protected sites for conserving biological diversity, monitoring minimally disturbed ecosystems, and undertaking non-destructive research and other low-impact uses (such as education); a clearly identified buffer zone, which usually surrounds or adjoins the core areas, and is used for cooperative activities compatible with sound ecological practices, including environmental education, recreation, ecotourism, and applied and basic research; and a flexible transition area, or area of co-operation, which may contain a variety of agricultural activities, settlements and other uses and in which local communities, management agencies, scientists, non-governmental organizations, cultural groups, economic interests and other stakeholders work together to manage and sustainably develop the area's resources UNESCO (1996).

Biosphere reserves are not considered to be conservation areas in Indonesia, although their core areas are aimed at the conservation of biodiversity. The point is that a biosphere reserve also includes buffer zones and transition areas. The management of a biosphere reserve area is implemented via a zoning system that combines conservation, development, and logistic functions (PHKA 2013). According to Indonesian Law Number 5 of 1990 on Conservation of Natural Resources and Ecosystems, a biosphere reserve is defined as an area that consisting of natural ecosystems, unique ecosystems, or degraded ecosystems, and the entire natural elements are protected and preserved for the benefit of research and education.

Many countries have been adopting the biosphere reserve concept because it serve human socio-economic interests as well as conservation needs. It provides for long term utilization while ensuring the survival/protection of the ecosystem resource (Batisse 1993). One such biosphere reserve in Indonesia is the Siberut Island Biosphere Reserve (SIBR) which is the focus of this study. The SIBR was declared in 1981 as representative of an island possessing lowland tropical rain forest ecosystems, as well as a location of unique wild life and local culture (BTNS 2010).

The objective of combining traditional land-use without side institutions that have a mandate for conservation is quite complicated and has potential to produce horizontal conflicts
(Kosmaryandi et al. 2012). Moreover, the model for recognition of land rights and of community access to stateowned forest areas is still far from ideal (Safitri 2010).

In order to ensure the sustainable utilization of FR by the Siberut community, the implementation of the SIBR concept requires effort and strategy. That is what the investigation reported here addresses; namely the collection and analysis of empirical data on Siberut FR, their utilisation by the local community, and the particular behaviors and utilisation practices that have implications for the management of the SIBR.

\section{Methods}

The research was conducted between September and October 2014 among the Siberut communities in 3 villages: Matotonan, Saibi Samukop, and Sagulubbek, within the Mentawai Islands Regency, West Sumatera Province, Indonesia. The location was selected purposively to represent 3 zones in the SIBR. Saibi Samukop Village is located in the transition area, Matotonan Village in the buffer zone, and Sagulubbek Village in the core area.

The research approach was qualitative using case study method (Yin 2014). Data were collected through a literature study, in-depth interviews, and direct observations. The analysis of data was carried out through a process of encoding and grouping data, then interpreting the grouped information to draw conclusions (Irawan 2006).

The literature comprised documentation from relevant agencies, and publications about Siberut community characteristics dan FR. In-depth interviews were carried out with 9 informants (3 each villages). Informants were determined purposively, the main criterion being that they had to have good knowledge of FR and its utilization by the community. Direct observations was carried out by carefully recording observed activity and behavior of people in utilizing FR. Biological resources were determined based on inventorying flora and fauna from sample plots. Sample plots were used to determined the flora at tree level in the forest, covering 0.2 ha per location (total 0.6 ha), while the fauna were assessed along a $500 \mathrm{~m}$ transect in each location (total $1.5 \mathrm{~km})$.

The data of flora and fauna collected included scientific and local names, as well as their benefits for the Siberut community. The category of "beneficial for the community" is according to the criterias of Pearce (1992) cited in Munasinghe (1993), which is that the FR have economic benefits if they can be consumed directly or value in generating cash, such as in the case of wood, food, recreation, and herbs. FR are ecologically beneficial if they provide ecological functions, such as flood control; water quality protection; protection against wind; germplasm resources; or protection of habitat, plants or animals. Furthermore, FR provide social benefits if they support indigenous and community cultural activities.

\section{Results and Discussion}

Characteristics of the Siberut community The Siberut community embraces a patrilineal system with the $u m a^{1}$ as focus of the social life (Schefold 1991). Life in the uma has been traditionally based on togetherness; work, food, forest 
products were all divided in the uma. Differences in social class were unknown in the Siberut community, and men in the uma were treated as social equals. Decisions were arrived at by consensus after discussions involving all the adult men of the uma.

Even though social class is unrecognized, there are certain figures who receive special respect from the communities, such as the chieftain (Sikebukat uma) and the Sikerei. The Sikebukat uma does not act as a solitary decision-maker in the $u m a$, but rather acts as a facilitator of an event, especially in the implementation of customs and traditions. The Sikerei is someone who has the ability to treat the disease and is believed to be able to communicate with spirits (bajou) or souls (simagre) (Schefold 1991).

According to Siberut's (Mentawaian) traditional belief called Arat Sabulungan, all living things and everything in nature have a spirit (Schefold 1991; Mulhadi 2008). A spirit can be separated from the body and roaming freely. If harmony between the spirit and the body is not maintained, the spirit will go and this will cause body aches and sickness. If daily activities are not in proper accordance with the customs and beliefs, this can disrupt the spiritual balance and harmony in nature. To maintain and restore harmony or avoid interference by spirits, a traditional ceremony called punen, puliaijat or lia is held. It is performed in conjunction with human activity. When such a ceremony is performed, the uma are decorated, pork is served, and dances (turuk) are held to the delight of the spirits, who will restore harmony (Schefold 1991). The traditional ceremony is performed by the Sikerei. During ceremonies, various restrictions (kei-kei) must be observed by Sikerei, uma members and/or family members, depending on the type of ceremony. These beliefs still exist and continue to be practiced in the daily lives of the community today (BTNS 2010).

Traditionally, all lands in Siberut were owned by uma. Utilization of land and other resources belonged to the uma just members only. Uma members could utilize another uma's land according to a loan system. The process consisted of borrowing the land through an agreement in the presence of witnesses. Uma land owners could earn money or things as a sign of agreement (pulajuk mone). Utilization of resources owned by the uma or by individuals, without permission, resulted in fines (tulou).

Utilization of forest resources Results from a study of the literature (30 documents since 1995 to 2015) on various aspects of research related to the biodiversity of Siberut illand are presented in Table 1. On record are 1,460 species of plants from 160 families; 38 species of mammals; 173 species of birds; 77 species of herpeto-fauna; 120 species of insects; and 32 species of freshwater fish. The results of this literatures study show that the number of biodiversity recorded for Siberut is greater than the number of biodiversity in the document for the Siberut National Park (2010), which states that on Siberut there are 846 species from 131 families of

${ }^{1} U m a$ is a political and economic unit in Mentawaian tribe, consisting of 2-10 main families or 10-60 individuals and also a unit of land ownership. In addition, uma also refers to the name of the custom house which serve as a gathering place and perform rituals (Darmanto \& Setyowati 2012). People from Siberut sometime using word suku to replace uma. flora; 134 species of birds; and 24 species of freshwater fish. The difference in reported numbers is caused by the fact that SNP (2010) used old data from a LIPI inventory in 1995. Based on current literatures, the biodiversity of the FR utilized directly or indirectly by the Siberut community can be grouped into 3 groups: resources providing an economic benefits, resources of ecological benefits, and source of benefits for social activities.

Source of economic benefits Based on interviews, there were 72 species of plants and animals that are often consumed by Siberut community (Table 1). There were 6 species of carbohydrate-producing plants, 30 species of fruits-producing plants, 16 species of vegetables-producing plants, as well as 20 species and group of animals as sources of protein. From the forest, Siberut communities also harvest forest products to generate cash income (BTNS 2010). Plants and animals that could generate cash consist of eight species, presented in Table 2. According to Pattanayak et al. (2003), forests product contribute significantly to rural economies in Siberut.

The forest inventory resulting from our sample plots identified 56 species of trees. They are listed in Table 3. Thirty of the species are sources of building materials. The results show that the forests have been a sources of the building materials for the Siberut community for centuries. This is very well understood, because the Siberut have 3 traditional types of house made of timber products. First is the $u m a$, which is large raised-platform house that extends to the rear and can be occupied by several families. The lalep are smaller, raised-house, built around the uma and occupied by single families. Finally, there are sapou sainak, which are shaped, raised-hut in the fields with space underneath used for raising livestock.

Plants used for firewood are as many as seventeen species. Almost all rural communities in Siberut still use firewood (Pattanayak et al. 2003). Firewood is plentiful in the forest but rarely taken by people because it is also widely available around the settlements as a result of cultivations. Basically, all wood can be used as fuel, but some species are preferred because longer burning, for example sabbui (Psidium guajava L.).

The Siberut community still use herbs as medicine. Two species of plants in our sample plots that have been used for medication are Durio graveolens Becc. and tegeiluk anitu. According to Ave \& Sunito (1990), 233 species of plants are used to cure 123 diseases. These are taken from the fields around their houses and from adjacent forests (Jafarsidik \& Sutomo 1995). The people used baiko (Artocarpus lanceifolius Roxb.) to make traditional cloth even though the Siberut people are now wearing clothes made from cotton. The bark of the plant is still used to produce strap and basket lanyards. Forests also produce timber through forest concessions, and then Siberut people (uma) obtain cash (pulajuk mone) for each cubic meter of wood harvested by the timber company (Darmanto \& Setyowati 2012).

Sago (Metroxylon sagu Rottb.), a staple food on the island, was not found within the sample plots because these plots were set on the hillside locations. However, sago plants are easy to find around the settlements. Naturally, sago 
Table 1 Plant and animal species that are often consumed by Siberut community ${ }^{a}$

\begin{tabular}{|c|c|c|c|c|c|}
\hline Scientific name & Local name & Description & Scientific name & Local name & Description \\
\hline \multicolumn{6}{|c|}{ Producing of carbohydrates } \\
\hline Metroxylon sagu Rottb. & Sagu & SF & Iротеа spp. & Gobik siputeteket & $\begin{array}{l}\text { Substitute of } \\
\text { SF, EK }\end{array}$ \\
\hline $\begin{array}{l}\text { Colocasia esculenta (L.) } \\
\text { Schott }\end{array}$ & Gette' & $\begin{array}{l}\text { Substitute of } \\
\text { SF }\end{array}$ & Manihot spp. & Gobik sipukaju & $\begin{array}{l}\text { Substitute of } \\
\text { SF, EK }\end{array}$ \\
\hline Musa spp. & Mago' & $\begin{array}{l}\text { Substitute of } \\
\text { SF }\end{array}$ & Oryza sativa $\mathrm{L}$. & Berak & $\begin{array}{l}\text { Substitute of } \\
\text { SF, EK }\end{array}$ \\
\hline \multicolumn{6}{|c|}{ Producing of fruits } \\
\hline Durio zibethinus L. & Doriat & & Carica spp. & Sakkoile & \\
\hline Durio carinatus Mast. & Toktuk & & $\begin{array}{l}\text { Flacourtia rukam Zoll. } \\
\text { \& Moritzi }\end{array}$ & Pattara & \\
\hline Durio malaccensis Planch. & Siposinoso & & Mangifera sp. 1 & Abangan & \\
\hline $\begin{array}{l}\text { ex Mast } \\
\text { Lansium parasiticum } \\
\text { (Osbeck) K.C. Sahni \& } \\
\text { Bennet }\end{array}$ & Tiat/Siamong & & $\begin{array}{l}\text { Mangifera sp. } 2 \\
\text { Syzygium sp. }\end{array}$ & $\begin{array}{l}\text { Bailoi } \\
\text { Sibeu/Sileu }\end{array}$ & \\
\hline Lansium sp. & Tiat Sibulu & & Horsfieldia sp. & Latco & \\
\hline Aglaia sp. 1 & $\begin{array}{l}\text { Tiat Turu } \\
\text { Goukgouk }\end{array}$ & & Baccaurea sp. & Sileu & \\
\hline Aglaia sp. 2 & Tiat Setcet & & $\begin{array}{l}\text { Artocarpus elasticus } \\
\text { Reinw. ex Blume }\end{array}$ & Baiko & \\
\hline $\begin{array}{l}\text { Radermachera gigantea } \\
\text { (Blume) Miq. }\end{array}$ & $\begin{array}{l}\text { Tiat Elak } \\
\text { Mata }\end{array}$ & & $\begin{array}{l}\text { Artocarpus integer } \\
\text { (Thunb.) Merr. }\end{array}$ & Peigu sareu & Ek \\
\hline Nephelium sp. & Babaet & & $\begin{array}{l}\text { Artocarpus } \\
\text { heterophyllus Lam. }\end{array}$ & Peigu & \\
\hline Nephelium lappaceum L. & $\begin{array}{l}\text { Bairabbit } \\
\text { sareu }\end{array}$ & Ek & Annona muricata $\mathrm{L}$. & Doriat sareu & Ek \\
\hline Psidium guajava $\mathrm{L}$. & Sabbui & & $\begin{array}{l}\text { Ananas comosus (L.) } \\
\text { Merr. }\end{array}$ & Asit & Ek \\
\hline Eugenia sp. & Karakau & & Citrus sp. & Muttei & \\
\hline $\begin{array}{l}\text { Syzygium malaccense (L.) } \\
\text { Merr. \& L.M.Perry }\end{array}$ & Ailuluppa' & & Citrus sp. & Kairinggi & \\
\hline Eugenia sp. & $\begin{array}{l}\text { Karakau } \\
\text { sasareu }\end{array}$ & Ek & Citrus sp. & Rimau & $\mathrm{Ek}$ \\
\hline \multicolumn{6}{|c|}{ Producing of vegetables } \\
\hline $\begin{array}{l}\text { Dendrocalamus asper } \\
\text { (Schult.) Backer }\end{array}$ & Emut metuk & & Zea mays L. & Jagung & Ek \\
\hline Gnetum gnemon L. & Tojet & & Capsicum sp. & Daro simabo'o & Ek \\
\hline $\begin{array}{l}\text { Allantodia aspera (Blume) } \\
\text { Ching. }\end{array}$ & Phaku & & Capsicum sp. & Daro siboitok & Ek \\
\hline $\begin{array}{l}\text { Diplazium esculentum } \\
\text { (Retz.) Sw. }\end{array}$ & Phaku & & $\begin{array}{l}\text { Solanum lycopersicum } \\
\text { L. }\end{array}$ & Tomat & EK \\
\hline Parkia speciosa Hassk. & Petai & Ek & Solanum melongena $\mathrm{L}$. & Taruang & Ek \\
\hline $\begin{array}{l}\text { Pithecellobium jiringa (Jack) } \\
\text { Merr. }\end{array}$ & Jariang & Ek & Solanum sp. & Rimbang & \\
\hline $\begin{array}{l}\text { Oncosperma tigillarium } \\
\text { (Jack) Ridl. }\end{array}$ & Ariribuk & & Cucumis sp. & Pakku & Ek \\
\hline Saccharum officinarum $\mathrm{L}$. & Kole & & Arachis hypogaea L. & & Ek \\
\hline \multicolumn{6}{|c|}{ Sources of animal protein } \\
\hline Sus scrofa L., 1758 & Sainak & & - & $\begin{array}{l}\text { Silolo'oinan } \\
\text { (shrimps) }\end{array}$ & \\
\hline Bos taurus L., 1758 & Jawi & Ek & - & Sosak (squireels) & 3 spesies \\
\hline $\begin{array}{l}\text { Gallus gallus domesticus L., } \\
1758\end{array}$ & Gouk-gouk & Ek & $\begin{array}{l}\text { Rhynchoporus } \\
\text { ferrugineus Olivier, } \\
1790\end{array}$ & Tamra & Juvenil \\
\hline $\begin{array}{l}\text { Capra aegagrus Erxleben, } \\
1777\end{array}$ & Mbek & EK & - & $\begin{array}{l}\text { Tutube } \\
\text { (dipterocarp } \\
\text { caterpillar) }\end{array}$ & Juvenil \\
\hline $\begin{array}{l}\text { Macaca siberu Fuen. \& Ols., } \\
1995\end{array}$ & Bokkoi & & $\begin{array}{l}\text { Varanus salvator Laur., } \\
1768\end{array}$ & Batek & \\
\hline $\begin{array}{l}\text { Presbytis potenziani Bon., } \\
1856\end{array}$ & Joja & & - & Teilek (frogs) & 3 spesies \\
\hline Simias concolor Mill., 1903 & Simakobu & & - & Burung (birds) & 10 spesies \\
\hline Hylobates klossii Mill., 1903 & Bilou & & - & Lokipat (turtles) & \\
\hline $\begin{array}{l}\text { Rusa unicolor Kerr, } 1792 \\
\text { Manis javanica Desm., } 1822\end{array}$ & Sileleuk-leuk & & - & $I b a$ (fishes) & 29 spesies \\
\hline
\end{tabular}

${ }^{\mathrm{a}}$ Interviews results; ${ }^{\text {}} \mathrm{SF}$ : staple food, Ek: exotic plants. 
Table 2 Plants and animals from the forests that can generate cash in Siberut

\begin{tabular}{|c|c|c|}
\hline Scientific name & Local name & Prices $^{\mathrm{d}}$ \\
\hline Calamus manan Miq. & Bebeget & $\begin{array}{l}{ }^{-1} \text { Size } \mathrm{L} \text { diamater } 36 \mathrm{~mm}=\mathrm{IDR} 8,000 / \mathrm{stem} \text {; diamater } 31 \mathrm{~mm}=\mathrm{IDR} \\
3,000 \mathrm{stem}^{-1} ; \text { size } \mathrm{M}=\mathrm{IDR} 1,500 \mathrm{stem}^{-1} ; \text { size } \mathrm{S}=\mathrm{IDR} 1,000 \mathrm{stem}^{-1}\end{array}$ \\
\hline Aquilaria malaccensis Lam. & Simoitek & $\begin{array}{l}\text { Lower class called teri IDR200,000-300,000 } \text { gram }^{-1} \text {, A class IDR } \\
3000,000 \text { gram }^{-1}\end{array}$ \\
\hline Cocos nucifera $\mathrm{L}$. & Toitet $^{\mathrm{b}}$ & IDR $4,000-5,000 \mathrm{~kg}^{-1}$ \\
\hline Daemonorops sp. & Taset & IDR $17,000 \mathrm{~kg}^{-1}$ \\
\hline Pogostemon cablin (Blanco) Benth. & Patikoilo & IDR 180,000 bottle $^{-1}$ \\
\hline Gracula religiosa L., 1758 & Mainong ${ }^{\mathrm{c}}$ & 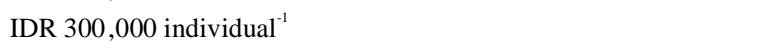 \\
\hline Copsychus malabaricus Scop., 1788 & Ratdat akek ${ }^{\mathrm{c}}$ & 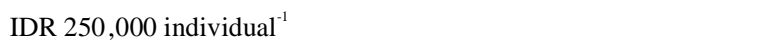 \\
\hline Copsychus saularis pagiensis Step., 1815 & Lut cabai ${ }^{\mathrm{c}}$ & IDR 50,000 individual $^{-1}$ \\
\hline
\end{tabular}

aLength $3 \mathrm{~m}$; ${ }^{\mathrm{b}}$ sold in the copra form; ${ }^{\mathrm{c}}$ sold in puppies; ${ }^{\mathrm{d}}$ prices at the villages level.

Table 3 Plants at the tree level in sample plots

\begin{tabular}{|c|c|c|c|c|c|}
\hline Scientific name & Local name & Benefit ${ }^{\mathbf{a}}$ & Scientific name & Local name & Benefit $^{\mathrm{a}}$ \\
\hline Endospermum diadenum (Miq.) Airy Shaw. & Alibakbak & $\mathrm{Pa}$ & - & Palak Bangi & $\mathrm{Pa}, \mathrm{Kb}$ \\
\hline- & Atipet & $\mathrm{Pa}$ & Garcinia sp. & Papat & $\mathrm{Pa}$ \\
\hline Drypetes sp. & Bahlo & $\mathrm{Pa}$ & Shorea sp. & Parabatti & $\mathrm{Pa}$ \\
\hline Aporosa sp. & Beliu & $\mathrm{Pa}$ & Dillenia indica $\mathrm{L}$. & Peileggut & $\mathrm{Pa}$ \\
\hline Shorea sp. & Boklo & $\mathrm{Pa}$ & $\begin{array}{l}\text { Allophylus cobbe } \\
\text { (L.) Raeusch. }\end{array}$ & Poilak bangi & $\mathrm{Kb}$ \\
\hline Swintonia sp. & $B u k-b u k$ & $\mathrm{Ub}$ & $\begin{array}{l}\text { Baccaurea brevipes } \\
\text { Hook.f. }\end{array}$ & Popok pok & $\mathrm{Ub}$ \\
\hline Eugenia longiflora (C.Presl) Fern. & Buluk Surak & $\mathrm{Ub}$ & $\begin{array}{l}\text { Eugenia cymosa } \\
\text { Lam. }\end{array}$ & Ribbu & $\mathrm{Pa}$ \\
\hline Elaeocarpus obtusus Blume & Buluk Surak & $\mathrm{Pa}$ & $\begin{array}{l}\text { Eugenia leneata } \\
\text { (Sw.) DC. }\end{array}$ & Ribbu & $\mathrm{Pa}, \mathrm{Kb}$ \\
\hline- & Darubei & $\mathrm{Pa}$ & $\begin{array}{l}\text { Horsfieldia irya } \\
\text { (Gaertn.) Warb. }\end{array}$ & Roat & $\mathrm{Ub}$ \\
\hline Syzygium sp. & $\begin{array}{l}\text { Deret } \\
\text { mainong }\end{array}$ & $\mathrm{Kb}$ & - & Sibelacit & $\mathrm{Ub}$ \\
\hline - & Gegebak & $\mathrm{Pa}$ & - & Sikokkok & $\mathrm{Kb}$ \\
\hline Knema sp. & Kalumanang & $\mathrm{Kb}$ & $\begin{array}{l}\text { Eugenia claviflora } \\
\text { Roxb. }\end{array}$ & Sipeuk peuk & $\mathrm{Kb}$ \\
\hline Vitex sp. & $\begin{array}{l}\text { Kapot } \\
\text { Leituak }\end{array}$ & $\mathrm{Kb}$ & $\begin{array}{l}\text { Rhodamnia cinerea } \\
\text { Jack }\end{array}$ & Sipulaiket & $\mathrm{Ub}$ \\
\hline Dipterocarpus sp. & Kara-kara & $\mathrm{Kb}$, So & - & Siputuddukat & $\mathrm{Pa}$ \\
\hline Shorea sp. & Karai & $\mathrm{Pa}$, So & Quercus robur $\mathrm{L}$. & Sitairak & $\mathrm{Pa}$ \\
\hline Parashorea plicata Brandis & Katuka & $\mathrm{Pa}$ & - & Soi-soi & $\mathrm{Ub}$ \\
\hline Shorea pauciflora King & Katuka & $\mathrm{Pa}$ & Litsea sp. & Surugi & $\mathrm{Pa}$ \\
\hline Syzygium papillosum (Duthie) Merr. \& L.M.Perry & Katu Kecat & $\mathrm{Pa}$ & - & Suksuk teilek & $\mathrm{Ub}$ \\
\hline Lithocarpus hystrix (Korth.) Rehder & Kekeinek & $\mathrm{Ub}$ & Goniothalamus sp. & $\begin{array}{l}\text { Sususrut } \\
\text { Bobro }\end{array}$ & $\mathrm{Pa}$ \\
\hline Dipterocarpus sp. & Koka & $\mathrm{Pa}, \mathrm{Kb}$ & $\begin{array}{l}\text { Elateriospermum } \\
\text { tapos Blume }\end{array}$ & Taima titi & $\mathrm{Ub}$ \\
\hline - & Kurau & $\mathrm{Pa}$ & $\begin{array}{l}\text { Artocarpus } \\
\text { lanceifolius Roxb. }\end{array}$ & Tapeiki & $\mathrm{Pa}, \mathrm{Sd}$ \\
\hline Polyalthia sp. & Lacco & $\mathrm{Ub}$ & - & Tebengen & $\mathrm{Ub}$ \\
\hline Carallia sp. & Lakut Masabi & $\mathrm{Pa}, \mathrm{Kb}$ & - & $\begin{array}{l}\text { Tegeiluk } \\
\text { Anitu }\end{array}$ & $\mathrm{Ok}$ \\
\hline Canarium rufum A.W.Benn. & Logau saba & $\mathrm{Kb}$ & - & Temei & $\mathrm{Kb}$ \\
\hline Hopea sp. & Macemi & $\mathrm{Pa}$ & $\begin{array}{l}\text { Drypetes polyneura } \\
\text { Airy Shaw }\end{array}$ & Toilat/Beliu & $\mathrm{Pa}$ \\
\hline Shorea sp. & Manegat & $\mathrm{Pa}$ & $\begin{array}{l}\text { Durio graveolens } \\
\text { Becc. }\end{array}$ & Toktuk Geta & $\begin{array}{l}\mathrm{Pa}, \mathrm{OK}, \\
\mathrm{Kb}\end{array}$ \\
\hline Knema laurina Warb. & $\begin{array}{l}\text { Ngalo } \\
\text { patadekat }\end{array}$ & $\mathrm{Kb}$ & - & Tupe lekak & $\mathrm{Ub}$ \\
\hline Knema hookeriana Warb. & Onga & $\mathrm{Kb}$ & $\begin{array}{l}\text { Chrysophyllum } \\
\text { roxburghii G.Don }\end{array}$ & Uru kulit & $\mathrm{Kb}$ \\
\hline
\end{tabular}

${ }^{a} \mathrm{Pg}$ : foods, Pa: building materials, Sd: clothing materials, Ok: medicines and cosmetics, So: materials for tools and social activities, Ub: unknown benefit. 
grows in the swamp ecosystems or in fields close to ponds (BTNS 2010).

The animals observed in the transects were 7 species of birds, 2 species of primates, and 1 caterpillar species (tutube) from dipterocarp tree (Table 4). Of the 7 species of birds, two can be directly consumed (Treron vernans Temminick, 1823 and Anthracoceros albirostris Temminck., 1832), 2 species can be used as pets (Oriolus chinensis L., 1766 and Antreptes malacensis Scop., 1786), and one species can be sold (Copsychus malabaricus Scop., 1788). These results show that forests as habitats for wildlife are important for the community. According to Quinten et al. (2014), the Siberut community have been obtaining protein by hunting wildlife from the forest up until the present day. The main animals hunted in the forests are primates ${ }^{2}$, deer (Cervus unicolor Kerr, 1792), and wild boars (Sus scrofa L., 1758). From river and swamp ecosystems, the community can harvest various kinds of fishes (iba), shrimps (silolo'oinan), frogs (teilek), clams, and crabs. Beside from forest, the Siberut community (Mentawai) fulfill their needs from fields; this is called mone (Febrianto \& Fitriani 2012).

Source of ecological benefits Siberut communities understand that the forests provide ecological benefits. This was clearly described by a key informant (Mr. Sudarmanto Satoleuru) in his statement "... if there is no forest there will be a flood, no canes, no monkeys ...". Based on the traditional knowledge, some species of plants are understood provide distinct ecological benefits, such as sokut (Ficus spp.) which can store water, bebeget (Calamus manan Miq.) which are indicators of soil fertility, and mangrove plants (Avicenia sp.) which can protect the edges of villages from strong winds.

Forests are also a source of plant germplasm for the community. According to the community, plants grown in fields originally derived from forests; for example, bebeget

${ }^{2}$ There are 4 species of Siberut endemic primates: bokkoi or Siberut monkey (Macaca siberu Fuen. \& Ols., 1995), bilou or dwarf gibbon (Hylobates klossii Mill., 1903), joja or Mentawai langur (Presbytis potenziani Bon., 1856), and simakobu or pig-tailed macaque (Simias concolor Mill., 1903). The primates are protected by Indonesian regulation.
(Calamus manan Miq.), simoitek (Aquilaria malaccensis Lam.), duriat (Durio spp.), tiat (Aglaia spp.), and babaet (Nephelium sp.). Plant seeds were often taken from the forest when people have activities in the forests, such as hunting animal or collecting forest products. The reasons for the community moving seedlings or seeds from the forests to their fields are to facilitate the maintenance, treatment, and harvesting of the plants. This finding is in agreement with the opinions of Zhang et al. (2013), that the utilization of forest plants is a strategy to maximize the number of useful species cultivated in gardens and yards and thus better fulfill the livelihood needs of traditional community.

Source of benefits for social activities In most traditional communities of Indonesia, social harmony is very dependent on customary practices. Likewise, life in the Siberut community is based on customs, called arat sabulungan (Schefold 1991). In these Siberut customs, biodiversity from the forests play a big role in organizing rituals. According to Soedjito (2006), such traditional knowledge and customs in the use of biodiversity is an embedded in the management of some Indonesian biosphere reserves.

Rituals procession in Siberut community utilize a lot of plants (Hernawati 2007). Plants are taken from the surrounding settlements, but if not enough is available they must be obtained from the forests. In our inventory of trees in the forest, 2 spesies of plants were identified that are socially useful as materials for carving (Dipterocarpus sp. and Shorea sp.). In addition, various plants are also used as markers of party occasions; for decoratively filling sacred objects in the house; as land markers; and as materials to be used in the ritual practices of the Sikerei (Tabel 5).

Beside plants, animals are an important part of the Siberut community social life. Animal hunting is not only to fulfill the needs for animal protein, but also facilitates the community's social activities. Hunting by men is carried out when the uma party (punen uma) is performed. The heart of the hunted animal is taken out and then examined for signs to

Table 4. Animals identified on the observation transect

\begin{tabular}{|c|c|c|c|c|c|c|}
\hline \multirow{2}{*}{ Scientific name } & \multirow{2}{*}{ Local name } & \multicolumn{3}{|c|}{ Number in age class } & \multirow{2}{*}{ Total } & \multirow{2}{*}{ Benefit $^{\mathrm{a}}$} \\
\hline & & Old & Adult & Young & & \\
\hline Treron vernans L. 1771 & Lemendeu & 0 & 1 & 0 & 1 & $\mathrm{~Pa}$ \\
\hline Oriolus chinensis sipora Linn. , 1766 & Tapporaok & 0 & 1 & 0 & 1 & $\mathrm{Pl}$ \\
\hline- & Tutube & 0 & 0 & 6 & 6 & $\mathrm{~Pa}$ \\
\hline Presbytis potenziani Bon., 1856 & Joja & 2 & 2 & 1 & 5 & $\mathrm{~Pa}$ \\
\hline Hylobates klossii Mill ., 1903 & Bilou & 0 & 2 & 0 & 2 & $\mathrm{~Pa}$ \\
\hline Ciconia episcopus Bodd., 1783 & Mayang & 0 & 1 & 0 & 1 & $\mathrm{Ub}$ \\
\hline Copsychus malabaricus Scop., 1788 & Ratdat akek & 0 & 0 & 1 & 1 & $\mathrm{Ju}$ \\
\hline Anthracoceros albirostris Shaw \& Nodder, 1807 & Kailaba & 0 & 1 & 0 & 1 & $\mathrm{~Pa}$ \\
\hline Antreptes malacensis Scop., 1786 & Satsat & 0 & 2 & 0 & 2 & $\mathrm{Pl}$ \\
\hline Centropus sinensis Ste ph., 1815 & Kemut & 0 & 1 & 0 & 1 & $\mathrm{Ub}$ \\
\hline
\end{tabular}

${ }^{\mathrm{a}} \mathrm{Pa}$ : consumption, Ju: sold to the traders, Pl: pets, Ub: unknown benefit. 
Table 5 Social activities and plants used by the Siberut community in social activities

\begin{tabular}{|c|c|c|c|}
\hline Social activities & Scientific name & Local name & Parts of plant are used \\
\hline Markers (panakiat) where a party & Arenga pinnata (Wurmb) Merr. & Poula & Tips \\
\hline is held (punen ) & Hibiscus rosa-sinensis $\mathrm{L}$. & Bekkeu & Flowers \\
\hline Markers (kinumbuk) where series & Arenga pinnata (Wurmb) Merr. & Poula & Tips \\
\hline of part ies are held & Saccha rrum officinarum $\mathrm{L}$. & Kole & Stem \& leafs \\
\hline Kirekat $^{4}$ trees & Durio ssp. & $\begin{array}{l}\text { Duriat, toktuk, } \\
\text { kinoso }\end{array}$ & Trunk \\
\hline \multirow[t]{4}{*}{ Kirekat tree marker } & Cordyline fruticosa (L.) A.Chev. & Bobloh & Planting \\
\hline & Codiaeum variegatum (L.) Rumph. ex & Sura' & Planting \\
\hline & A. Juss. & Aileleppet & Planting \\
\hline & $\begin{array}{l}\text { Graptophyllum pictum (L.) Griff. } \\
\text { Zingiber sp. }\end{array}$ & Simakainan & Planting \\
\hline \multirow{8}{*}{$\begin{array}{l}\text { Fill sacred objects (buluat) in the } \\
\text { house (lalep) and small house in } \\
\text { the garden (sapou sainak) }\end{array}$} & Calamus manan Miq & Bebeget & Roots \& stem \\
\hline & Clerodendrum chinense (Osbeck) & Rabu & Roots \& small branch \\
\hline & Mabb. & Pulak bangi & Roots \& small br anch \\
\hline & Parinarium sp. & Bobloh & Leafs \\
\hline & Cordyline fruticosa (L.) A.Chev. & Sura' & Leafs \\
\hline & Codiaeum variegatum (L.) Rumph. ex & & \\
\hline & A.Juss. & Soga & Leafs \\
\hline & $\begin{array}{l}\text { Phymatosorus membranifolium (R. } \\
\text { Br.) S.G. Lu }\end{array}$ & & \\
\hline \multirow[t]{9}{*}{ Sikerei ritual s } & Mussaenda frondosa $\mathrm{L}$. & Mumunen & Leafs \\
\hline & $\begin{array}{l}\text { Codiaeum variegatum (L.) Rumph. ex } \\
\text { A.Juss. }\end{array}$ & Sura'sibeugak & Leafs \\
\hline & Codiaeum sp. & Sura' siboitok & Leafs \\
\hline & Graptophyllum pictum (L.) Griff. & Aileleppet & Leafs \\
\hline & Cordyline fruticosa (L.) A.Chev. & Bobloh & Leafs \\
\hline & Antidesma neurocarpum Miq. & Kelak baga & Leafs \\
\hline & Arenga pinnata (Wurmb) Merr. & Poula & Leafs \\
\hline & Hibiscus rosa-sinensis $\mathrm{L}$. & Bekkeu & Flowers \\
\hline & Hedychium coronarium J.Koenig & Simakainao & Leafs \\
\hline Land owner marker $\mathrm{s}$ & Codiaeum spp. & Sura' & Planting \\
\hline
\end{tabular}

predict good or bad, according to their traditional knowledge. If the signs of the heart are bad the hunting will continue and if the signs of the heart are good the hunting will be stopped. Meat of the hunted animals is consumed and the heart of auspicious animals given to children who have not yet participated in an eneget ${ }^{3}$.

Various traditional equipment within the Siberut community is made from several trees from the forests, such as the traditional communication tool called tuddukat. Tuddukat is a large, shaped gong placed in the ground. This instrument serves to disseminate information to the public about events, such as informing about hunted yields or death. The tuddukat is made from kulip wood (Vitex sp.) or babaet (Nephelium sp.), and the drum stick (tetektek) is made of lakobak wood (Garcinia sp.), alolosit, or uru kulit.

Instruments for artistic purposes are also observed in the Siberut community. For example, there are musical instruments such as drums (gajeuma') made from poula trunks (Arenga pinnata (Wurmb) Merr.), with their membranes made from batek leathers (Varanus salvator Laur., 1768) or ulow saba skins (Python reticulatus Schn.,

${ }^{3}$ Eneget is ceremony for introduction of hunting to a boy. The present of the animal heart is intended to ensure that the boy will become expert in hunting.

${ }^{4}$ Kirekat is a memorial for those who died. The memorial depicted in a particular tree belonged to the deceased person or in a panel board (Schefold 1991).
1801). These are used to accompany tradisional dances (turuk). There are also carving and images made from forest resources, such as kirekat which is a symbol for a person who has died; birds carving (umat simagre) as a toy for the spirits; and plates and dishes. The wood used for these carvings and images are gite (Alstonia spp.) or peigu (Artocarpus integer (Thunb.) Merr.), due to the fact that these woods are soft and easy to shape. In addition, there are war shield (koraibi) made from woods of katuko (Shorea spp.) or kulip (Vitex spp.).

Household appliances are traditionally made from plants taken from the forests. There were several types of baskets (opa) of various shapes, sizes, and functions. Generally, opa are made of wicker from pelege (Calamus javensis Blume), with shoulders strap made of baiko bark (Artocarpus sp.) and with a cover of wicker (bobolat) made from the stem of sago. $O p a$ is important in daily activities; besides being useful for carrying farm products, they are also used as containers for various things. In addition, traditional mats (jarakjak) are made from sasa (Calamus caesius Blume).

Hunting and fishing equipment are also taken from the forests. Animals hunting equipment are bows (rou-rou) and arrows (silogui). Bows are made from poula stem (Arenga sp.), shafts made of osi (Daemonorops propinqua Becc.), and arrowheads made from poula glued with onam sap (Calamus sp.). Tubes (bukbuk) for storing the darts are made 
of bamboo covered by sago fronds, and fitted with a bukbuk rope made of woven coconut coir (Cocos nucifera L.). Fishing equipment consists of traps (leggeu) made of poula sticks and tied fine rattan (Calamus sp.), and subba nets made of nylon netting supported by a frame made from two small rattan rods. Animal traps for use in the forest are formed from a rope noose made from palm fiber strands. A trap for birds or bats is made of bamboo rods tipped with poula smeared with sap of peigu (Artocarpus integer (Thunb.) Merr.). Primates traps are made from bamboo cane tied with a rope, and placed in the canopy of trees.

From the above explanations regarding the benefits of FR, it can be seen that the forests are a vital source of Siberut community life. These results support the claim that there is an intimate relationship between culture and forest in Siberut Island (Schefold 1991; Persoon 2001). Negi (2010) asserted that the plants of the forest have the potential to preserve the cultures and indigenous knowledge of local communities. Our observations confirm this in the case of the Siberut community.

Behavior changes in the community's utilization of forest resources Traditional belief of Siberut teach that humans live must be harmony with nature (Mulhadi 2008). However, in line with the times, the community's interaction with other incoming cultural influences are tending to weaken traditional values, beliefs and customary rules. These changes include the appearance of new unwise behavior in the people's utilization of FR. The adoption of new incoming technologies has perceived benefits in enabling people to utilize the forest resources more easily and rapidly but they are often at the expense of the long term health and sustainability of these resources.

The breaking of traditional abstinences rules (kei-kei) are examples of the kinds of observed behavioral changes we list in Table 6. Activities carried out in disobedience of particular traditional restrictions suggest a weakening of the system of customary law that has existed in society up until recent times (Suhartini 2009). According to Coronese (1986), abstinence laws are rules that regulate human behavior in social life and a product of a culture. The weakening of such values can be a reason for concern.
Policy implications The main objectives of the biosphere reserve management is sustainable development. Sustainable development is defined as "development that meets the needs of the present without compromising the ability of future generations to meet their needs". In pursuit of this objective, the management of the Biosphere Reserve employs a land zoning system consisting of three components: a core area, a buffer zone, and a transition area (Soedjito 2004). Accordingly, the SIBR has 3 zones comprising:

1 the core area (190,500 ha), which is the declared area of the Siberut National Park with the objective of conserving biodiversity,

2 the buffer zones (128,277 ha) consisting of forest areas with functions of production, protection and conservation, as well as the Saibi Sarabua Marine Park, with the objective to ensuring the protection of the core area and the utilization of natural resources in a sustainable manner,

3 the transition areas (84,223 ha) consisting of the APL (lands used for interests outside the forestry sector) and private land which is an area for regency and community development.

Although the declaration of a biosphere reserve changes the way the particular land areas are managed and may be used, it does not change ownership of the land. The owners of the SIBR still continue to have land rights and manage their land as their own. However, the biosphere reserve zoning system does direct the way the different land zones can be utilized. Thus, the important role for SIBR manager is to coordinate and negotiate the utilization activities of the stakeholders, especially making efforts to empower the communities in the implementation of the biosphere reserve (Soedjito 2004). Community empowerment is carried out to ensure that the community reach a consensus in accepting and following the rules about the reserve, without reducing the revenue obtain from the forest.

In accordance with traditional lands ownership system of the Siberut communities, all the lands are owned by the uma, and each member of uma is entitled to utilize FR in their uma land. This mean, there are no lands within the SIBR that can't be utilized by the uma and each uma member agrees to

Table 6 Siberut community behavioral changes in their forest resources utilization

\begin{tabular}{|c|c|c|c|}
\hline $\begin{array}{c}\text { Forest resource } \\
\text { utilization activities }\end{array}$ & Traditionally & Contemporary & Reasons \\
\hline $\begin{array}{l}\text { Hunt animals in the } \\
\text { forest }\end{array}$ & $\begin{array}{l}\text { Using arrows with poisoned } \\
\text { darts }\end{array}$ & $\begin{array}{l}\text { Using air rifle with toxic } \\
\text { bullets }\end{array}$ & $\begin{array}{l}\text { Adoption of technology from } \\
\text { abroad, to obtain faster results }\end{array}$ \\
\hline Fishing in the river & $\begin{array}{l}\text { Using tangguk (net with rattan } \\
\text { frame) }\end{array}$ & Using toxic substance & $\begin{array}{l}\text { Adoption of technology from } \\
\text { abroad, to obtain faster results }\end{array}$ \\
\hline Harvesting rattan manau & Drawn from the trees & $\begin{array}{l}\text { Cutting down from the } \\
\text { trees }\end{array}$ & To obtain faster results \\
\hline Cutting big trees & Ceremony (punen) be held & Direct cutting & No effect on life safety \\
\hline $\begin{array}{l}\text { Land clearing for } \\
\text { cultivation }\end{array}$ & Ceremony (punen) be held & $\begin{array}{l}\text { Direct processed when } \\
\text { used paddy land }\end{array}$ & No effect on life safety \\
\hline $\begin{array}{l}\text { Clearing lands for plant } \\
\text { cultivation }\end{array}$ & The plants slashed not burned & $\begin{array}{l}\text { Some people s begun } \\
\text { burn ing the slashed } \\
\text { plants }\end{array}$ & Land processing more faster \\
\hline Harvesting (trees, sago) & $\begin{array}{l}\text { When people saw mayang bird } \\
\text { or snake near trees, people } \\
\text { believed its bad omen sign }\end{array}$ & $\begin{array}{l}\text { Natural signs are } \\
\text { ignored }\end{array}$ & No effect on life safety \\
\hline
\end{tabular}


Table 7 The documents about Siberut biodiversity reviewed in this study

\begin{tabular}{|c|c|c|}
\hline Documents & Authors & Year \\
\hline Integreted Conservation Management Plan: Siberut National Park (1995-2020) & $\begin{array}{l}\text { Directorat Forest Protection and } \\
\text { Nature Conservation, Ministy of } \\
\text { Forestry, Indonesia }\end{array}$ & 1995 \\
\hline $\begin{array}{l}\text { Traditional theraphy and medical plants at Sirisurak and Tei-Tei Batti Game } \\
\text { Reserve, Saibi, Siberut in Journal of Forest Research Bulletin 587:45-58 }\end{array}$ & Jafarsidik Y, Sutomo S & 1995 \\
\hline $\begin{array}{l}\text { Interaksi manusia dan hutan, suatu pendekatan etnobotanis: Studi kasus masyarakat } \\
\text { Siberut, Sumatera Baratin Proceeding of Indonesian } 2^{n d} \text { Etnobotani Seminar, pages: } \\
520-527\end{array}$ & Walujo EB, Abdulhadi R & 1995 \\
\hline $\begin{array}{l}\text { Feeding and ranging in the Mentawai Island langur (Presbytis poten ziani) in } \\
\text { International Journal of Primatology 17(4):525-548 }\end{array}$ & Fuentes A & 1996 \\
\hline $\begin{array}{l}\text { The lethal arrow poison in the traditional tribal community of Siberut Island, } \\
\text { Indonesia in Journal of Tropical Ethnobiology 1(2):30-37 }\end{array}$ & Zarhorka H & 1999 \\
\hline Birds of Siberut, Mentawai Islands, West Sumatera in Journal of Kukila 11:73-96 & Kemp N & 2000 \\
\hline Secondary succession after se & Simbolon $\mathrm{H}$ & 2001 \\
\hline
\end{tabular}

in Taileleu Village, Siberut Island National Park, West Sumatra in Journal of Berita

Biologi 5(4):405-411

Ekosistem Hutan Mangrove, pages:88-96

Biomass and carbon content at forest production in Siberut Island Biosphere Reserve, West Sumatra in Journal of Forest Research and Nature Conservation 5(5):397-407

Orchids in Siberut National Park in Siberut National Park Report

Studi ekologi perladangan hutan tradisional masyarakat Mentawai (pumonean) di

Pulau Siberut, Sumatera Barat in Proceeding of Man and Biosphere Charter 2005

for Indonesia Young Researchers and Environment Practitioners

Mammals in Siberut National Park in Siberut National Park Report

Konservasi primata endemik Mentawai: Analisis habitat dan populasi primata di

Siberut Utara in Proceeding of Expose of Research Results in Indonesia Forestry

Research and Development Centre, pages:63-69

Studi ko-habitasi antara simakobu (Simias concolor) dan Joja (Presbytis potenziani) di area Siberut Conservation Program (SCP), Pulau Siberut, Kepulauan Mentawai, Sumatera Barat in Bogor Agriculture University Script

Struktur vegetasi habitat Simakobu (Simias concolor) di area Siberut Conservation Program (SCP), Pulau Siberut, Kepulauan Mentawai, Sumatera Barat in Bogor Agriculture University Script

An inventory of reptiles and amphibians in North-West of Siberut Island, West Sumatra in Journal of Zoo Indonesia 17(2):35-48

Survey of the Primate Community of Peat Swamp Forests on Siberut, Mentawai Islands (Indonesia) in Georg-August-Universitat Gottingen Thesis

Peat swamp forest supports high primate densities on Siberut Island, Sumatra, Indonesia in Journal of Oryx 44(1):147-151

Keanekaragaman herpetofauna di areal Siberut Conservation Program (SCP),

Pulau Siberut, Kepulauan Mentawai, Sumatera Barat in Bogor Agriculture

University Script

Tree diversity and forest structure in northern Siberut, Mentawai Islands, Indonesia in Journal of Tropical Ecology 50(2):315-327

Potensi jenis dipterocarpaceae di Cagar Biosfer Siberut in Plasma Nutfah Bulletin 16(1):64-71

Aspects feeding competition in wild siberut macaques (Macaca siberu) in Georg -

August-Universitat Gottingen Thesis

Butterflies in Siberut Island in Siberut National Park Report

Reptiles and amphibians in Siberut National Park in Siberut National Park Report

Ornament plants in Siberut National Park in Siberut National Park Report

Preferensi pohon tidur kelompok joja (Presbytis potenziani) di Siberut Utara,

Kepulauan Mentawai in Indonesia University Script

Vertical and horizontal habitats of fruit-feeding butterflies (Lepidoptera) on Siberut,

Mentawai Islands, Indonesia in Journal of Ecotropica 17:79-90

Habitat use and tropic niche overlap of two sympatric colobines, Presbytis

potenziani and Simias concolor, on Siberut, Indonesia in International Journal of

Primatology 33:218-232

Subiandono E, Bismark M,

Heriyanto NM

Bismark M, Heriyanto NM,

Iskandar S

Yunaidi, Ainas N

Darmanto

2006

Nopiansyah F, Suyanto A

Rahayuni DR

Handayani YD

Sidik I

Quinten MC

Quinten MC, Waltert M, Syamsuri F, Hodges JK.

Widyananto $\mathrm{R}$

Hadi S, Ziegler T, Waltert M,

Subiandono E, Bismark M, Heriyanto NM

Gras P

Nopiansyah F, Imo Y, Mahyudin

First etimates of primate density and abundance in Siberut National Park, Mentawai Quinten MC, Nopiansyah F,

Islands, Indonesia in Journal of Oryx pages:1-4

Hodges JK

Fisheries survey in Mentawai Waters Bengkulu Province in Journal of Procedia Enviromental Sciences 24:238-244 
manage the FR in a manner reached by consensus. For example, people can accept or reject a concession to harvest timber on their uma lands, depending on the agreement of the uma. Following on from this, it is an important role of the SIBR that it empowers people to manage their FR according to the best management practices, while at the same time realizing the objectives of the biosphere reserves concept. Liambi et al. (2005) has asserted that the active participation of the local community determines the success of conservation efforts. Accordingly, IPBES (2013) recognized that indigenous peoples and members of local communities must have distinct status as knowledge holders and rightsholders in such endeavors.

The biosphere reserves concept is a form of 'conservation discourse' that derives from outside Siberut communities institutions (Darmanto 2011). Nevertheless, the Siberut community is encouraged to maintain traditional institutions, patterns of resource use, and sustainable practices within the biosphere reserve framework. According to Kafiar (2013), accomodating local communities, with respect for their institutions, can avoid social conflicts in the implementation of new initiatives of this kind. However, at this point in time an organizing committee for the SIBR has not yet been established. An organizing committee will play an important role in media consultancy, advocacy, human resource development, funding, and innovative for sustainable utilization (Soedjito 2004). The organizing committee should involve representatives of all stake-holders, especially those from the local community (Sheng-Ji 2013; Iswandono 2015). This is a crucial step to realize sustainable development in the SIBR.

\section{Conclusion}

Forest resources of the Siberut Island Biosphere Reserve (SIBR) are sources of economic, ecological, and social benefits for the Siberut community, controlled by their traditional, consultative, headship of relationships, known as the uma. Recent changes in the people's behavior in the use of forest resources have the potential to adversely affect the achievement of the objectives of SIBR management. Therefore, SIBR management policies need to accommodate long-established traditional utilization practices, by endorsing local institutions, and strengthening sustainable development. The management policies must be integrated in a committee comprising stakeholders, especially elements of the local community, with a mandate for media consultation, advocacy, human resource development, fundraising, and for the development of wise, innovative, natural resource use technologies.

\section{Acknowledgement}

The authors are very grateful to the Centre for Forestry Education and Training, Ministry of Environment and Forestry, of Republic of Indonesia, for a scholarship and budget support given to accomplish this research.

\section{References}

Ave W, Sunito S. 1990. Medical Plants of Siberut. Jakarta: WWF International.
Batisse M. 1993. Biosphere reserves: an overview. Nature and Resources 29:1-4.

[BTNS] Balai Taman Nasional Siberut. 2010. Rencana Strategis Balai Taman Nasional Siberut Tahun 2010 2014. Padang: BTNS.

Coronese S. 1986. Kebudayaan Suku Mentawai. Jakarta: Grafidian Jaya Press.

Darmanto. 2006. Studi ekologi perladangan hutan tradisional masyarakat Mentawai (Pumonean) di Pulau Siberut, Sumatera Barat. In: Soedjito H, editor. Piagam MAB 2005 untuk Peneliti Muda dan Praktisi Lingkungan di Indonesia. Jakarta: LIPI Press.

Darmanto, Setyowati AB. 2012. Berebut Hutan Siberut: Orang Mentawai, Kekuasaan, dan Politik Ekologi. Jakarta: Kepustakaan Populer Gramedia.

Dassir M. 2008. Pranata sosial sistem pengelolaan hutan masyarakat adat Kajang. Jurnal Hutan dan Masyarakat 3:111-234.

[DFID] Departement for International Development. 1999. Sustainable Livelihoods Guidance Sheets. London: DFID.

Febrianto A, Fitriani E. 2012. Orang Mentawai: Peladang tradisional dan ekonomi pasar. Humanus 11:119-133.

Hernawati TS. 2007. Uma: Fenomena Keterkaitan Manusia dengan Alam. Padang: Yayasan Citra Mandiri.

[IPBES] Intergovernmental Platform on Biodiversity and Ecosystems Services. 2013. The Contribution of Indigenous and Local Knowledge Systems to IPBES: Building Synergies with Science. Co-edited by $\mathrm{R}$. Thaman, P. Lyver, R. Mpande, E. Perez, J. Cariño and K. Takeuchi, IPBES Expert Meeting Report, UNESCO/UNU. Paris: UNESCO.

Irawan P. 2006. Penelitian Kualitatif dan Kuantitatif untuk Ilmu-ilmu Sosial. Jakarta: Universitas Indonesia Press.

Ishwaran N, Persic A, Tri NH. 2008. Concept and practice: the case of UNESCO biosphere reserves. Journal Environment and Sustainable Development 7:118-131.

Iswandono E, Zuhud EAM, Hikmat A, Kosmaryandi N. 2015. Integrating local culture into forest conservation: A case study of the Manggarai Tribe in Ruteng Mountains, Indonesia. Jurnal Manajemen Hutan Tropika 21:55-64. http://dx.doi.org/ 10.7226/jtfm.21.2.55.

Jafarsidik Y, Sutomo S. 1995. Pengobatan tradisional dan jenis tumbuhan obat di Sirisurak dan kawasan Suaka Margasatwa Tei-tei Batti Saibi, Siberut. Penelitian Hutan $587: 45-48$.

Kafiar FP. 2013. Kearifan lokal Suku Amungme dalam pengelolaan sumber daya alam dan lingkungan di Kabupaten Mimika Papua. Jurnal Ekosains 5:35-43. 
Kosmaryandi N, Basuni S, Prasetyo LB, Adiwibowo S. 2012. New Idea for National Park Zoning System: a Synthesis between Biodiversity Conservation and Customary Community's Tradition. Jurnal Manajemen Hutan Tropika 18:69-77. http://dx.doi.org/10.7226/jtfm.18.2.69.

Liambi DL, Smith KJ, Pereira N, Pereira AC, Valero F, Monasterio M, Davila MV. 2005. Participatory planning for biodiversity conservation in the high tropical Andes: Are farmers interested? Mountain Research and Development 25:200-205.

Mulhadi. 2008. Kepercayaan tradisional "Arat Sabulungan" dan penghapusannya di Mentawai. Jurnal Equality 13:5065 .

Munasinghe M. 1993. Environmental Economics and Sustainable Development. World Bank Environmental Paper Number 2.

Negi CS. 2010. Traditional culture and biodiversity conservation: Examples from Uttarakhand, Central Himalaya. Montain Research and Development 30:259-265. http:// dx.doi.org/10.1659/MRD-JOURNAL-D-09-00040.1.

Persoon GA. 2001. The management of wild and domesticated forest resources in Siberut, West Sumatra. Journal Antropologi Indonesia 64:69-83.

[PHKA] Direktorat Jenderal Perlindungan Hutan dan Konservasi Alam. 2013. Rencana Pengelolaan Terpadu (Integreted Management Plan) Cagar Biosfer Pulau Siberut Tahun 2013-2022. Jakarta: PHKA dan Komite Nasional MAB Indonesia.

Quinten M, Stirling F, Schwarze S, Dinata Y, Hodges K. 2014. Knowledge, attitudes and practices of local people on Siberut Island (West-Sumatra, Indonesia) towards primate hunting and conservation. Journal of Threatened Taxa 6: 6389-6398. http://dx.doi.org/10.11609/JoTT.o3963 6389-98

Safitri MA. 2010. Legalisasi hak-hak masyarakat atas tanah dan kekayaan alam dalam peraturan perundang-undangan nasional Indonesia: Model, masalah dan rekomendasi. In: Masa Depan Hak-Hak Komunal atas Tanah: Beberapa Gagasan untuk Pengakuan Hukum. Jakarta: BAPPENAS.

Sheng-Ji P. 2013. Ethnobotany dan the sustainable use of biodiversity. Plant Diversity and Resources 35:401-406.

Soedjito H. 2004. Pedoman Pengelolaan Cagar Biosfer di
Indonesia. Jakarta: Komite Nasional MAB Indonesia, LIPI.

Soedjito H (Ed.). 2006. Kearifan Tradisional dan Cagar Biosfer di Indonesia: Prosiding Piagam MAB 2005 untuk Peneliti Muda dan Praktisi Lingkungan di Indonesia. Jakarta: Komite Nasional MAB Indonesia, LIPI.

Pattanayak SK, Sills EO, Mehta AD, Kramer RA. 2003. Local uses of parks: Uncovering pattern of household production from forest of Siberut, Indonesia. Conservation and Society 1:209-222.

Schefold R. 1991. Mainan bagi roh: Kebudayaan Mentawai. Jakarta: Pustaka Jaya Press.

Sheil D, Puri R, Wan M, Basuki I, Heist MV, Lisnawati N Rukmiyati RI, Samsoedin I. 2006. Recognizing local people's priorities for tropical forest biodiversity. Ambio 35:17-24. http://dx.doi.org/10.1579/0044-7447-35.1.17.

Suhartini. 2009. Kajian kearifan lokal masyarakat dalam pengelolaan sumber daya alam dan lingkungan. In: Prosiding Seminar Nasional Penelitian, Pendidikan dan Penerapan MIPA, Fakultas MIPA Universitas Negeri Yogyakarta; Yogyakarta, Mei 16, 2009. Pp B207-B218.

Turner NJ, Luczaj LJ, Migliorini P, Pieroni A, Dreon AL, Sacchetti LE, Paoletti MG. 2011. Edible and tended wild plants. Critical Reviews in Plant Sciences 30:198-225. http://dx.doi.org/10.1080/07352689.2011.554492.

[UNESCO] United Nations Educational Scientific and Cultural Organization. 1996. Biosphere Reserve: The Seville Strategy and the Statutory Framework of the Network. Paris: UNESCO.

Walujo EB, Supardijono. 1997. Ikatan antara masyarakat Siberut dengan sumber daya alam hayati di sekitarnya. In: Walujo EB, Susanto H, Adhikerana AS, editors. Pulau Siberut: Potensi, Kendala dan Tantangan Pembangunan. Bogor: Puslitbang Biologi-LIPI.

Yin RK. 2014. Studi Kasus, Desain dan Metode. Djauhi MM, translator. Translate from: Case Study Research: Desain and Methods. Edition 13. Jakarta: Penerbit Rajawali Press.

Zhang LL, Zhang Y, Wang L, Wang YH. 2013. An ethnobotanical study of traditional edible plants used by Naxi people in Nortwest Yunnan, China. Plant and Diversity Resources 35:479-486. http://dx.doi.org/ 10.7677/ynzwyj201313063. 